\title{
Development and Validation of an ELISA at Acidic pH for the Quantitative Determination of IL-13 in Human Plasma and Serum
}

\author{
Julie Doucet, An Zhao, Jean Fu, and Alexandre Avrameas \\ Department of Marker Localization and Assays, Biomarker Development, Novartis Institutes for Biomedical Research, \\ 4056 Basel, Switzerland
}

Correspondence should be addressed to Julie Doucet; julie.doucet@novartis.com

Received 21 June 2013; Revised 25 July 2013; Accepted 3 August 2013

Academic Editor: Kishore Chaudhry

Copyright (C) 2013 Julie Doucet et al. This is an open access article distributed under the Creative Commons Attribution License, which permits unrestricted use, distribution, and reproduction in any medium, provided the original work is properly cited.

\begin{abstract}
A novel sandwich ELISA for the quantitative and sensitive determination of IL-13 in human serum and plasma was established. The assay employs an incubation step at acidic $\mathrm{pH}$, which was shown to decrease nonspecific binding and interference from IL-13 binding proteins. The assay was validated and was shown to be accurate and precise over the entire quantification range (0.59 to $68.4 \mathrm{pg} / \mathrm{mL}$ in human EDTA plasma). The validated assay was successfully applied to samples from healthy volunteers and patients with atopic seasonal rhinitis. The assay is suitable for use in clinical trials to monitor efficacy or pharmacodynamic effects of drug candidates.
\end{abstract}

\section{Introduction}

Interleukin-13 (IL-13) is an immunoregulatory cytokine secreted by $\mathrm{T}$ helper 2 lymphocytes. As being involved in the activation of IgE production, eosinophil infiltration, mucus hyper secretion, and subepithelial fibrosis, IL-13 is a central mediator in the inflammation of airways and in the pathogenesis of asthma and allergy $[1,2]$. This cytokine and its receptors have therefore emerged as important targets and biomarkers for new therapeutic approaches to the treatment of asthmatic and allergic diseases [1].

In human, IL-13 has already been measured in bronchoalveolar lavage fluid (BAL) allowing to distinguish asthmatic children from control subjects [3]. However, BAL samples are very difficult to obtain, and therefore studies in children have been restricted [4]. IL-13 has also been measured in other airway fluids such as nasal lavage fluid [5], nasopharyngeal aspirates [6], and sputum [7], but all these matrices also require inconvenient collection procedures. There have been several attempts to measure IL-13 in less invasive fluids such as serum, using different immunoassay methods. These studies report a broad range of IL-13 concentrations in the serum from healthy subjects: from $0.25 \mathrm{pg} / \mathrm{mL}$ using a microparticle-based immunoassay $[8,9]$ to 8.1 and
$92.3 \mathrm{pg} / \mathrm{mL}$ using two different commercial ELISA methods $[10,11]$. While the two studies using ELISA methods could correlate systemic IL-13 concentration with asthmatic status, the third study could not distinguish healthy and asthmatic subjects based on this measurement. It therefore appears that the determination of IL-13 concentrations in serum is method dependent, and this may reflect different method performances. Particular care should be taken to validate the method in terms of specificity, sensitivity, and reproducibility to qualify its performances for the accurate measurement of endogenous IL-13 in human serum. We also hypothesize that binding partners of IL-13 may interfere in the assay and explain at least part of the observed variability. Interleukin13 indeed binds to several different receptors, including IL13R $\alpha 1$, IL-13R $\alpha 2$, and IL-4R $\alpha$ [12]. The soluble form of IL$13 \mathrm{R} \alpha 2$ has been observed in the serum of mice at levels reaching several $\mathrm{ng} / \mathrm{mL}[13]$ and in the BAL fluid of humans (up to $400 \mathrm{pg} / \mathrm{mL}$ ) [14]. Soluble IL-13R $\alpha 2$ has never been detected in the serum from humans but methods described to support these observations had detection limits above $125 \mathrm{pg} / \mathrm{mL}[13,15]$. If sIL-13R $\alpha 2$ circulates in human serum in the low $\mathrm{pg} / \mathrm{mL}$ range, it may interfere with the measurement of IL-13. 
Here we report the development and validation of a sensitive, accurate, and reproducible assay for the quantification of IL-13 levels in human plasma and serum. The assay employs the sandwich ELISA technique built on commercially available reagents. Samples are incubated with the capture antibody at acidic $\mathrm{pH}$ to strip IL-13 from any of its binding partners. We applied the validated assay to measure total circulating IL-13 in atopic patients and compared to levels obtained in apparently healthy controls.

\section{Material and Methods}

2.1. Reagents and Buffers. Immobilizer Amino 96-well microtiter plates were purchased from Nunc (Roskilde, Denmark). Antibodies and IL-13 standard protein were taken from the human IL-13 Module Set (Bender Medsystems, Vienna, Austria). IL-13R $\alpha 2$ (sIL-13R $\alpha 2-F c)$ was purchased from R\&D Systems (Minneapolis, MN). Amdex streptavidin-alkaline phosphatase (AP) was purchased from Amersham Biosciences (Fairfield, CT). Substrate for alkaline phosphatase with amplification system and fetal bovine serum (FBS) were obtained from Invitrogen (Carlsbad, CA). Bovine serum albumin (BSA) was from Sigma (St. louis, $\mathrm{MO}$ ). In plasma assay, horseradish-peroxidase- (HRP-) conjugated streptavidin from Bender Medsystems was used instead of streptavidin-AP. Ultra-TMB from Thermo was used as substrate of HRP. Coupling buffer was made of $100 \mathrm{mM}$ sodium dibasic phosphate ( $\mathrm{pH}$ 8.0). Washing buffer was PBS with $0.05 \%(\mathrm{v} / \mathrm{v})$ Tween 20 (PBST). Blocking buffer was composed of PBST with 3\% (w/v) BSA and 5\% (w/v) sucrose. Assay buffer was prepared with PBS, 0.05\% (v/v) Tween 20 , and $1 \%$ BSA.

2.2. Human Serum and EDTA Plasma Samples. Human serum and plasma samples used in assay development were obtained from the Etablissement français du Sang d'Alsace (Strasbourg, France) and from an internal blood donation program (Novartis AG, Basel, Switzerland). They were collected on presumably healthy and untreated individuals.

Human plasma samples for assay validation and sample analysis were obtained from Bioreclamation Inc., both from healthy and atopic subjects. A donor is determined to be "healthy" based on criteria set by either the Food and Drug Administration or the American Association of Blood Banks (AABB).

Human plasma samples from atopic subjects were collected based on following criteria set: male or female subjects aged between 18 and 60 years (inclusive) and in good health as determined by past medical history, physical examination, vital signs, electrocardiogram, and laboratory tests. Subjects must have a history of atopy, defined as a history of seasonal allergic rhinitis for at least 2 years (in relation to the ragweed season), and evidence of atopy, defined as a positive skin prick test (wheal difference allergen-negative control $\geq 3 \mathrm{~mm}$ ) to ragweed allergen at screening.

For serum collection, whole blood was drawn into a dry collection bag and allowed to clot overnight in a refrigerator and spun to serum at 2,800 $\times \mathrm{g}$ for 20 minutes in a refrigerated centrifuge $\left(5^{\circ} \mathrm{C}\right)$.

For EDTA plasma collection, whole blood was drawn into a collection bag containing anticoagulant and mixed gently for 5 minutes. The blood was allowed to sit at room temperature for 30 minutes and spun to plasma at $2,800 \times \mathrm{g}$ for 20 minutes in a refrigerated centrifuge $\left(5^{\circ} \mathrm{C}\right)$.

All samples were obtained with the appropriate informed consents.

2.3. Calibrators Preparation. Calibrators samples (Cs) were prepared freshly everyday by successive dilution of IL-13 standard protein in substitute matrix. Substitute matrix was made of $80 \% \mathrm{FBS} / 20 \%$ human serum. Human serum used in substitute matrix was selected for having a nondetectable endogenous IL-13 level.

Cs were incubated for $1 \mathrm{~h}$ with gentle shaking at room temperature before dilution (see next paragraph).

2.4. Sample Dilution. All samples (Cs, quality controls (QCs) and unknown samples) are first diluted 1:2 in one of the following buffers to reach, respectively, $\mathrm{pH} 7.4, \mathrm{pH} 5.0$, or $\mathrm{pH}$ 3.5:

(i) $\mathrm{PBS} / 0.1 \%$ Tween $20 / 6 \%$ BSA ( $\mathrm{pH} 7.4$ ),

(ii) MES $1 \mathrm{M} / 0.1 \%$ Tween $20 / 6 \%$ BSA (pH 4.9),

(iii) $\mathrm{HCl} /$ glycine $3 \mathrm{M} / 0.1 \%$ Tween $20 / 6 \%$ BSA (pH 3.4).

QCs and unknown samples are then further diluted up to $1: 3$ or more in the following buffers with corresponding $\mathrm{pH}$ values:

(i) PBS/0.05\% Tween $20 / 3 \%$ BSA/50\% FBS (pH 7.4),

(ii) MES $0.5 \mathrm{M} / 0.05 \%$ Tween $20 / 3 \%$ BSA/50\% FBS (pH 5.0),

(iii) $\mathrm{HCl} /$ glycine $1.5 \mathrm{M} / 0.05 \%$ Tween $20 / 3 \%$ BSA/50\% FBS ( $\mathrm{pH} 3.5)$.

All samples are analyzed by ELISA immediately after dilution.

2.5. ELISA. This protocol describes the ELISA procedure used during assay development. For assay validation, a few modifications were made to the procedure and are reported wherever applicable.

A mouse monoclonal anti-human IL-13 capture antibody was covalently coupled to microtiter plates. To do so, a $2.5 \mu \mathrm{g} / \mathrm{mL}$ solution in coupling buffer was incubated overnight at $4^{\circ} \mathrm{C}(100 \mu \mathrm{L} /$ well $)$. For assay validation and sample analysis, the coating solution was modified to $3.5 \mu \mathrm{g} / \mathrm{mL}$ in coupling buffer. Wells were then emptied and blocked with $300 \mu \mathrm{L} /$ well blocking buffer during $2 \mathrm{~h}$ and $30 \mathrm{~min}$ at room temperature with $200 \mathrm{rpm}$ shaking. The plates were then washed three times with $300 \mu \mathrm{L} /$ well washing buffer. $100 \mu \mathrm{L} /$ well of Cs, QCs, and unknown samples, diluted following the above described procedure, were then pipetted in duplicate into predetermined wells and incubated overnight at $4^{\circ} \mathrm{C}$ with shaking. After washing three times 
with $300 \mu \mathrm{L} /$ well washing buffer, detection antibody (biotinylated mouse monoclonal anti-human IL-13 antibody), diluted $1: 1500$ in assay buffer, was incubated for $1 \mathrm{~h}$ at $100 \mu \mathrm{L} /$ well at room temperature with $200 \mathrm{rpm}$ shaking. Plates were then washed three times with $300 \mu \mathrm{L} /$ well washing buffer, and streptavidin-alkaline phosphatase (1:20000 in assay buffer) was added at $100 \mu \mathrm{L} /$ well. After $1 \mathrm{~h}$ incubation at room temperature with shaking, plates were washed three times with $300 \mu \mathrm{L} /$ well washing buffer and then three times with $300 \mu \mathrm{L} /$ well tris-buffered saline (TBS). Alkaline phosphatase substrate solution was then incubated at $50 \mu \mathrm{L} /$ well in the dark, at room temperature, and with shaking for 30 minutes. Amplifier solution was then pipetted ( $50 \mu \mathrm{L} /$ well $)$ and wells were further incubated for 15 minutes. For assay validation and sample analysis, the detection system was changed into streptavidin-HRP (1:2500 in assay buffer, $100 \mu \mathrm{L} /$ well), incubated for $1 \mathrm{~h}$ at room temperature with shaking. After washing, Ultra-TMB substrate was added (100 $\mu \mathrm{L} /$ well) in the wells and incubated for 30 minutes in the dark with shaking. The reaction was stopped by adding $50 \mu \mathrm{L} /$ well $2 \mathrm{~N}$ $\mathrm{H}_{2} \mathrm{SO}_{4}$ stop solution and further incubated for 5 minutes at room temperature in the dark with shaking. Optical density was read at $495 \mathrm{~nm}$ (AP detection) or $450-570 \mathrm{~nm}$ (HRP detection) with a SpectraMax M5 ELISA plate reader (Molecular Devices, Sunnyvale, CA). Calibration curve was established using a five-parameter curve fitting model and a $1 / y^{2}$ weighting factor (SoftMax Pro 5.2, Molecular Devices, Sunnyvale, CA).

Nonspecific binding (NSB) signal was obtained after the incubation of a plasma or serum sample, diluted into the appropriate buffer solution, in a well devoid of capture antibody.

2.6. Validation of IL-13 Assay in Human Plasma. The validation of the IL-13 assay under acidic conditions was evaluated by assessing calibration curve, intrarun accuracy and precision, interrun accuracy and precision, sensitivity/working range, parallelism and selectivity of IL-13, interference with IL-13R alpha2, and stability in biological matrix. The approach for assay validation was detailed in a previous report [16]. Details of the criteria for each parameter are described in Section 3.

2.7. Sample Analysis. The IL-13 concentration was determined in duplicate in human plasma samples by using IL13 assay under acidic conditions ( $\mathrm{pH}$ 3.5). Each sample analysis run contained a calibration curve, a zero standard, and three levels of QC samples covering the assay working range. Two independent preparations of each QC level were assayed in duplicate. The QCs and samples were diluted 1:2 according to the minimum required dilution (MRD). The sample measurement was considered acceptable only when acceptance criteria for both Cs and QCs are met and the CV\% of the duplicate measurement was less than or equal to $30 \%$, and the two values of the duplicate measurements were equal or above the LLOQ. Values measured below the LLOQ were assigned the value LLOQ/2 $(0.3 \mathrm{pg} / \mathrm{mL})$.
TABLE 1: Background signal and detection limit of rhIL-13 obtained at different incubation $\mathrm{pH}$ values.

\begin{tabular}{lcccc}
\hline & pH 7.4 & pH 5 & pH 3.5 & pH 3.25 \\
\hline Background signal (OD495) & 0.260 & 0.115 & 0.108 & 0.105 \\
Detection limit (pg/mL) & 0.31 & 0.16 & 0.31 & 5.00 \\
\hline
\end{tabular}

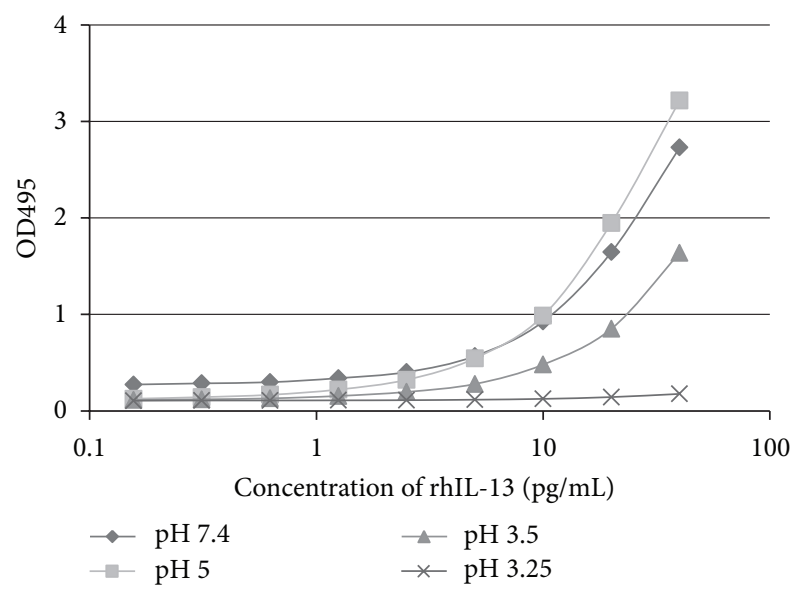

Figure 1: Titration curves of rhIL-13 incubated at $\mathrm{pH} 7.4, \mathrm{pH} 5, \mathrm{pH}$ 3.5 , and $\mathrm{pH} 3.25$ on immobilized capture antibody.

\section{Results}

3.1. Effect of $p H$ on Binding Activity of Recombinant IL-13 to Immobilized Capture Antibody. We evaluated binding activity of rhIL-13 to immobilized capture antibody at different incubation $\mathrm{pH}$ values: $\mathrm{pH} 7.4, \mathrm{pH} 5, \mathrm{pH} 3.5$, and $\mathrm{pH}$ 3.25. The obtained titration curves were displayed in Figure 1: titration curves of rhIL-13 incubated at $\mathrm{pH} 7.4, \mathrm{pH} 5, \mathrm{pH} 3.5$, and $\mathrm{pH} 3.25$ on immobilized capture antibody. Background signal and detection limit at the different $\mathrm{pH}$ values were reported in Table 1: background signal and detection limit of rhIL-13 obtained at different incubation $\mathrm{pH}$.

Background signal (OD) is the signal generated with all reagents but in absence of the specific analyte, the IL13 protein. Detection limit is the lowest calibration point for which the concentration can be back-calculated on the regression curve with 80 to $120 \%$ accuracy and with CV below $20 \%$.

Binding activity of rhIL-13 to capture antibody was not affected at pH 5 as compared to more classical and physiological conditions ( $\mathrm{pH}$ 7.4). However, background signal was reduced by half. At $\mathrm{pH} 3.5$, binding activity of rhIL-13 was strongly reduced: the signal generated by $40 \mathrm{pg} / \mathrm{mL}$ of rhIL13 was twice as less as at $\mathrm{pH}$ 5. Nevertheless, detection limit remained low, at $0.31 \mathrm{pg} / \mathrm{mL}$. At lower $\mathrm{pH}(\mathrm{pH} 3.25)$, rhIL13 could be detected only starting from $5 \mathrm{pg} / \mathrm{mL}$, meaning that capture by the immobilized antibody at this level of concentration was not possible or negligible at this $\mathrm{pH}$.

3.2. Effect of $p H$ on Nonspecific Binding (NSB) of Plasma Samples. At pH 7.4 (classical incubation conditions for an ELISA), the NSB observed with plasma samples was high and 


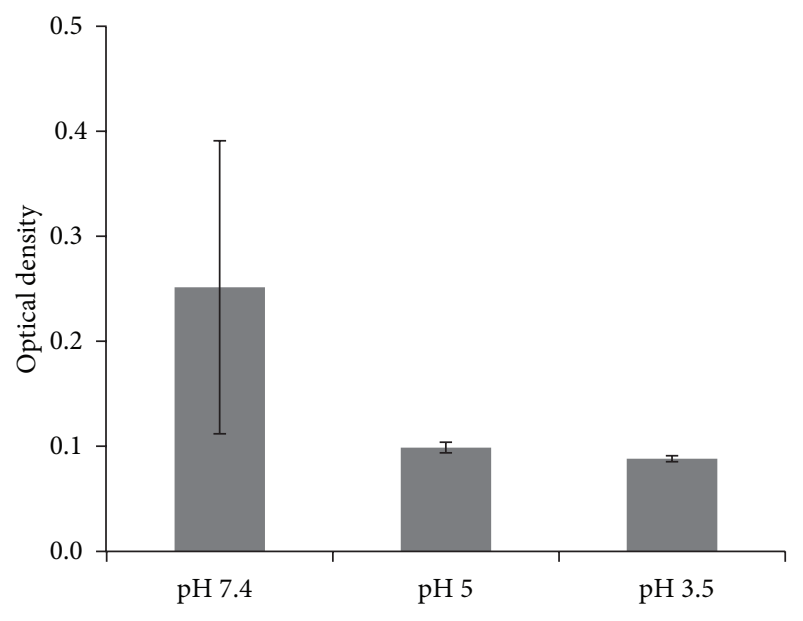

FIGURE 2: NSB obtained in plasma samples at $\mathrm{pH} 7.4, \mathrm{pH} 5$, and $\mathrm{pH}$ 3.5. NSB is the signal obtained by the detection (biotinylated antiIL13 antibody and enzyme linked streptavidin) of plasma components nonspecifically bound to the plate surface in the absence of capture antibody.

variable from one sample to another (Figure 2). Incubation of the same samples at lower $\mathrm{pH}(\mathrm{pH} 5$ and $\mathrm{pH} 3.5)$ allowed to reduce NSB and to homogenize it among samples.

The high NSB observed at $\mathrm{pH} 7.4$ indicated that measures obtained at this $\mathrm{pH}$ in plasma samples could not be considered as specific to the presence of IL-13. Hence, in the following paragraphs, measures of IL-13 concentration obtained at $\mathrm{pH} 7.4$ were not reported.

3.3. Effect of pH on the Reproducibility of Endogenous IL13 Quantification in Human Plasma. In the previous paragraphs, it has been shown that incubation of plasma samples at $\mathrm{pH} 5$ or $\mathrm{pH} 3.5$ allowed to reduce nonspecific signal while keeping good assay sensitivity. In this paragraph, endogenous concentrations of IL-13 were measured at these $\mathrm{pH}$ values on three independent runs in order to evaluate assay reproducibility (Figure 3). At pH 3.5, the obtained measurements were much more reproducible than those at $\mathrm{pH} 5$ (mean \% CV over 3 days: $10.1 \%$ at $\mathrm{pH} 3.5$ and $36.9 \%$ at $\mathrm{pH}$ 5). The lack of reproducibility observed at $\mathrm{pH} 5$ may be explained by a poor specificity of the method or by a poor accessibility of IL-13 to capture and/or detect antibodies (for instance due to the presence of binding proteins).

3.4. Effect of Binding Proteins at $p H 5$ and $p H 3.5$ on the Quantification of IL-13 in Human Serum. The interference of recombinant soluble human IL-13 $\mathrm{R} \alpha 2$ (one of the potential binding partners of IL13) was evaluated on the quantification of IL-13 at pH 5 and $\mathrm{pH} 3.5$ (Figure 4).

A human serum was spiked with $10 \mathrm{pg} / \mathrm{mL}$ rhIL-13 and high concentrations of rhIL-13R $\alpha 2$ ( 5 and $50 \mathrm{ng} / \mathrm{mL})$. After a $1 \mathrm{~h}$ incubation at room temperature (judged sufficient to allow interactions to occur between the two proteins), samples were adjusted to $\mathrm{pH} 5$ and $\mathrm{pH}$ 3.5. IL-13 was then measured in these samples.

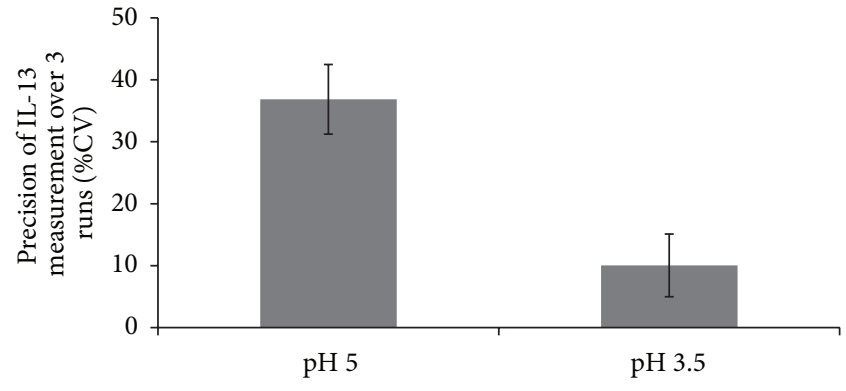

FIGURE 3: Interrun precision of endogenous IL-13 measurement in two human plasma samples at $\mathrm{pH} 5$ and $\mathrm{pH}$ 3.5. The endogenous IL-13 concentration was measured at $\mathrm{pH} 5$ and $\mathrm{pH} 3.5$ in three independent runs. Precision (\% CV) of the three measures was calculated for the two plasma samples.

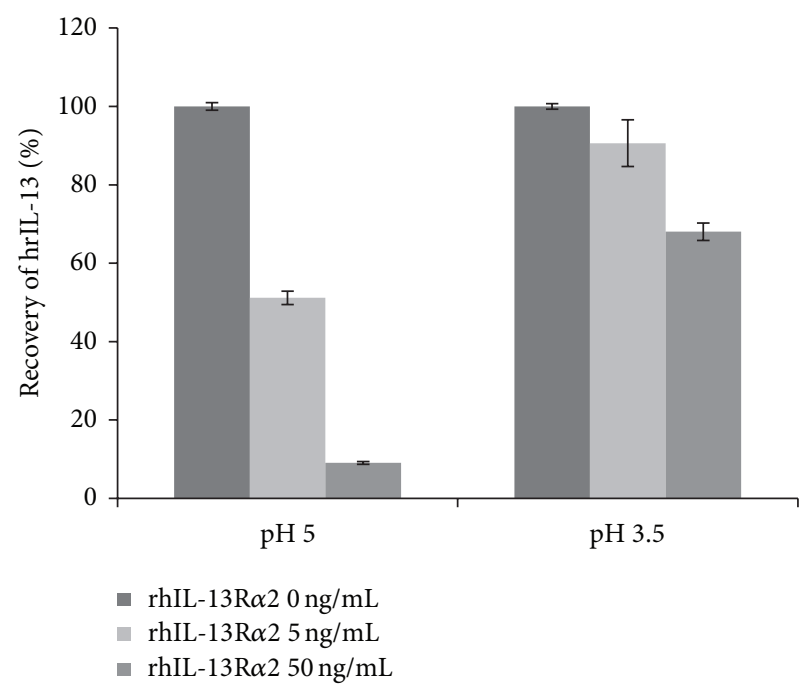

FIGURE 4: Recovery of rhIL-13 concentration in the presence of its receptor rhIL-13R $\alpha 2$ as a function of incubation $\mathrm{pH}$. rhIL-13 $(10 \mathrm{pg} / \mathrm{mL})$ and its receptor were spiked in a human serum. IL-13 concentration was then measured by ELISA at $\mathrm{pH} 5$ and $\mathrm{pH} 3.5$.

At $\mathrm{pH} 5$, the measure of $10 \mathrm{pg} / \mathrm{mL}$ rhIL-13 was inhibited in the presence of its receptor rhIL13R $\alpha 2$ : recovery was $51.2 \%$ in the presence of $5 \mathrm{ng} / \mathrm{mL}$ rhIL13R $\alpha 2$ and $9.1 \%$ in the presence of $50 \mathrm{ng} / \mathrm{mL}$. When bound to rhIL-13, the receptor inhibited the binding of capture and/or detection antibodies to rhIL13. The fraction of IL-13 detected by ELISA under these conditions corresponded to free IL-13 and possibly to a part of bound IL-13 in competition between the receptor and assay antibodies. In contrast, when $10 \mathrm{pg} / \mathrm{mL}$ of rhIL-13 was tested at $\mathrm{pH} 7.4,100 \%$ was inhibited in the presence of $50 \mathrm{ng} / \mathrm{mL}$ rhIL13R $\alpha 2$ (data not shown).

At $\mathrm{pH} 3.5$, recovery of rhIL-13 in the presence of rhIL13R $\alpha 2$ was improved: $90.1 \%$ in the presence of $5 \mathrm{ng} / \mathrm{mL}$ rhIL13R $\alpha 2$ and $68.1 \%$ in the presence of $50 \mathrm{ng} / \mathrm{mL}$. Acidification of samples to a $\mathrm{pH}$ of 3.5 modified interactions between IL-13 and its receptor so that epitopes recognized by assay antibodies were set free for binding to capture and detection antibodies. 
The effect of rhIL-13R $\alpha 2$ was also assessed on the measurement of endogenous IL-13 but no effect (until $50 \mathrm{ng} / \mathrm{mL}$ ) could be observed, whether at $\mathrm{pH} 5$ or at pH 3.5 (Figure 5). In the absence of a positive control of the binding of rhIL-13R $\alpha 2$ to endogenous IL-13, no conclusion about the effect of $\mathrm{pH}$ on the endogenous IL-13/rhIL-13R $\alpha 2$ complex could be drawn.

These results showed that acidic conditions ( $\mathrm{pH} 3.5$ ) were able to modify interactions between IL-13, binding proteins, and assay antibodies, so that the total (bound and free) concentration of IL-13 was measured. The improvement of assay precision on endogenous IL-13 measurement at $\mathrm{pH}$ 3.5 may be linked to the reduction of binding proteins interference. Besides, sample acidification allowed to reduce nonspecific signal generated by matrix components as shown in Section 2.3.

\subsection{Validation of IL-13 Assay in Human Plasma}

3.5.1. Calibration Curve. A calibration curve was run on each 96-well assay plate using the IL-13 standard provided with the assay kit. The curve was based on 12 calibrators (Cs) of recombinant human IL-13 diluted in 11 calibrators diluents (at $\mathrm{pH} 3.5$ ) in the range of 0.16 to $40.00 \mathrm{pg} / \mathrm{mL}$. Calibration curve data is shown in Table 2. Back-calculated concentration of the calibration standards in the range of $0.16-40.00 \mathrm{pg} / \mathrm{mL}$ met the acceptance criteria of mean accuracy within the range of $80-120 \%$ and precision (\% CV) less than $20 \%$.

3.5.2. Parallelism and Selectivity of IL-13 Assay. Neat plasma samples were tested pure and after dilution (direct or serial) to assess the endogenous levels of IL-13 and to evaluate the parallelism of the assay. Six different lots of human plasma samples were freshly diluted in sample diluent $(\mathrm{pH} 3.5)$ at $1: 2,1: 3,1: 4$, and $1: 6$ dilutions. The accuracy of the IL-13 determination in each individual diluted sample was within the range of 82.0 to $124.8 \%$ as compared to the values determined at dilution 1:2 (Table 3). This demonstrated that there was no apparent effect of dilution on IL-13 measurement from $1: 2$ to $1: 6$ dilutions in human plasma.

The same 6 different lots of human plasma were spiked with $25.0 \mathrm{pg} / \mathrm{mL}$ of recombinant human IL-13, and accuracy was assessed at $1: 2,1: 3,1: 4,1: 12$, and $1: 36$ with assay buffer. The spiking solution represented $<10 \%$ of the final volume. The accuracy of measurement of spiked plasma samples was ranging from 97.8 to $137.2 \%$ as shown in Table 4 . Overall, the data showed that the biological matrix does not interfere with the quantitative determination of IL-13 in human plasma. The minimum required dilution on this assay was shown to be $1: 2$.

3.5.3. Intrarun and Interrun Accuracy and Precision and Sensitivity/Working Range. Five quality controls (QCs) prepared with endogenous or spiked IL-13 in human plasma were selected at the lower limit of quantification (LLOQ), low (within 3 times the LLOQ), mid (midpoint on calibration curve), high (60-80\% of the ULOQ), and upper limit of quantification (ULOQ) levels. QCs were run over three independent runs, three independent determinations per QC level. Nominal values for each QC was determined as the mean of the nine determinations performed and used as reference values for the inter- and intrarun accuracy and precision assessments.

Intrarun and interrun accuracy and precision were assessed using five independent determinations of each QC level over six validation runs. Each validation run was validated based on standard curve and the following acceptance criteria for QCs: accuracy of $70-130 \%$ from nominal value, $\mathrm{CV} \leq 25 \%$, and at least 4/5 determination of each QC passing the criteria. The intrarun accuracy and precision were calculated for each QC level as the mean accuracy and the precision of the five measurements per run. The interrun accuracy and precision were calculated for each QC level as the mean accuracy and precision of all measurements performed.

All three runs passed the acceptance criteria. The overall intrarun and interrun accuracy and precision were shown in Table 5. The intrarun accuracy was within the range of $84.6 \%$ to $116.2 \%$ and precision (\% CV) within the range of $1.1 \%$ to $11.2 \%$. The interrun accuracy was within the range of 98.2 to $105.5 \%$ and precision (\% CV) within the range of 5.0 to $12.6 \%$.

The working range was defined by the LLOQ and ULOQ, whereby the sensitivity of the method was defined by the LLOQ (concentration at which the IL-13 concentration in human plasma could be quantitatively determined with acceptable precision and accuracy). The sensitivity of this IL-13 assay was $0.59 \mathrm{pg} / \mathrm{mL}$ in human plasma, taking into account the predilution of $1: 2$ required before analysis.

3.5.4. Interference of IL-13R Alpha 2 with IL-13 Measurement. Three individual human plasmas were spiked with $100 \mathrm{ng} / \mathrm{mL}$ IL-13R alpha 2 and analyzed after dilution in sample diluent from $1: 2,1: 3$, and $1: 4$. The recovery of endogenous IL-13 level was within the range of 76.8 to $125.8 \%$ in the presence of rhIL-13R $\alpha$. This demonstrated that rhIL-13R $\alpha 2$ does not interfere with the quantitative determination of IL-13 in human plasma.

3.5.5. Stability of IL-13 in Human Plasma. The stability of IL13 was investigated by analyzing two different lots of human plasma containing endogenous IL-13, stored undiluted under different storage conditions and time periods or subjected to 3 freeze (at -20 and $-80^{\circ} \mathrm{C}$ for at least 24 hours) and thaw (at RT for at least 3 hours) cycles. Each stability sample was analyzed in duplicate and three independent preparations. Recovery was assessed against the concentration measured at Day 1 (T0). The results showed (Table 6) that endogenous IL-13 concentrations in human plasma were stable for at least 1 week at $25^{\circ} \mathrm{C}$, two weeks at $4^{\circ} \mathrm{C}$, one month at $-20^{\circ} \mathrm{C}$, one month at $-80^{\circ} \mathrm{C}$, and after 3 freeze and thaw cycles. Longterm stability assessment was still ongoing at the time of reporting data.

3.6. Validation of IL-13 Assay in Human Serum. The assay was validated in human serum in a similar fashion as described for human plasma. The assay also demonstrated excellent performance, with a validated LLOQ of $0.27 \mathrm{pg} / \mathrm{mL}$ in serum, 


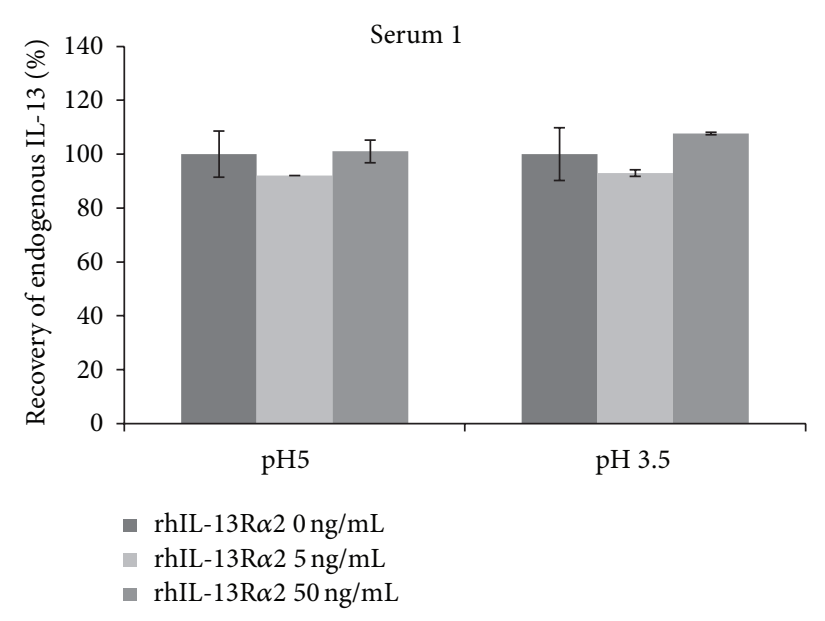

(a)

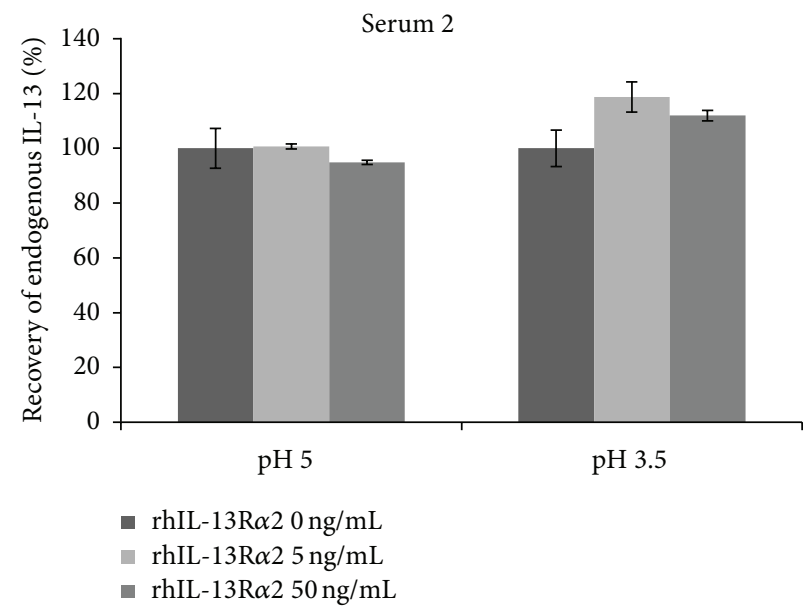

(b)

FIGURE 5: Recovery of endogenous IL-13 concentration in the presence of rhIL-13R $\alpha 2$ as a function of incubation pH. IL-13 was measured in two human serums spiked with rhIL-13R $\alpha 2$. The IL-13 concentration measured in the absence of spiked rhIL-13R $\alpha 2$ was taken as reference for the calculation of IL-13 recovery.

TABLE 2: Typical IL-13 calibration curve data obtained during assay validation.

\begin{tabular}{|c|c|c|c|c|c|c|c|c|}
\hline $\begin{array}{l}\text { IL-13 standard } \\
\text { concentration } \\
(\mathrm{pg} / \mathrm{mL})\end{array}$ & Wells & $\mathrm{OD}$ & OD mean & CV (\%) & $\begin{array}{c}\text { BackCalc } \\
\text { mean }\end{array}$ & $\begin{array}{c}\text { BackCalc } \\
\mathrm{Cv} \text { in } \%\end{array}$ & Accuracy (\%) & $\begin{array}{l}\text { Accuracy } \\
\text { mean (\%) }\end{array}$ \\
\hline \multirow{2}{*}{40} & A11 & 3.038 & & & & & 97.05 & \\
\hline & A12 & 3.108 & 3.073 & 1.6 & 39.6 & 2.86 & 101.06 & 99.05 \\
\hline \multirow{2}{*}{30} & B11 & 2.543 & & & & & 97.78 & \\
\hline & B12 & 2.64 & 2.592 & 2.6 & 30.2 & 3.9 & 103.33 & 100.56 \\
\hline \multirow{2}{*}{20} & C11 & 1.897 & & & & & 99.27 & \\
\hline & $\mathrm{C} 12$ & 1.955 & 1.926 & 2.1 & 20.2 & 2.65 & 103.06 & 101.16 \\
\hline \multirow{2}{*}{10} & D11 & 1.024 & & & & & 97.07 & \\
\hline & D12 & 1.091 & 1.058 & 4.5 & 10.1 & 5.04 & 104.25 & 100.66 \\
\hline \multirow{2}{*}{5} & E11 & 0.556 & & & & & 97.48 & \\
\hline & E12 & 0.561 & 0.559 & 0.5 & 4.9 & 0.62 & 98.34 & 97.91 \\
\hline \multirow{2}{*}{2.5} & F11 & 0.333 & & & & & 102.45 & \\
\hline & $\mathrm{F} 12$ & 0.324 & 0.328 & 1.8 & 2.5 & 2.46 & 98.94 & 100.7 \\
\hline \multirow{2}{*}{1.25} & G11 & 0.21 & & & & & 98.51 & \\
\hline & G12 & 0.215 & 0.213 & 1.5 & 1.3 & 2.93 & 102.68 & 100.6 \\
\hline \multirow{2}{*}{0.63} & H11 & 0.161 & & & & & 104.68 & \\
\hline & $\mathrm{H} 12$ & 0.158 & 0.159 & 1.6 & 0.6 & 4.81 & 97.79 & 101.23 \\
\hline \multirow{2}{*}{0.31} & D9 & 0.135 & & & & & 102.43 & \\
\hline & D10 & 0.139 & 0.137 & 2.2 & 0.3 & 11.35 & 120.31 & 111.37 \\
\hline \multirow{2}{*}{0.21} & E9 & 0.124 & & & & & 83.33 & \\
\hline & E10 & 0.126 & 0.125 & 0.7 & 0.2 & 6.75 & 91.69 & 87.51 \\
\hline \multirow{2}{*}{0.16} & F9 & 0.123 & & & & & 96.95 & \\
\hline & F10 & 0.122 & 0.123 & 0.5 & 0.1 & 5.82 & 89.29 & 93.12 \\
\hline
\end{tabular}

taking into account a minimum required dilution of $1: 2$. Intrarun accuracy and precision were in the range of 78.6$123.5 \%$ and $1.9-21.2 \%$, respectively. Interrun accuracy and precision were in the range of $99.1-109.7 \%$ and $9.7-19.5 \%$, respectively.
3.7. Distribution of IL-13 in Healthy and Atopic Subjects. The validated IL-13 assay was applied to determine concentration of IL-13 in plasma samples from 30 atopic seasonal rhinitis patients and 34 healthy subjects. Endogenous IL-13 can be detected in $46.5 \%$ of human healthy subjects with a median of 


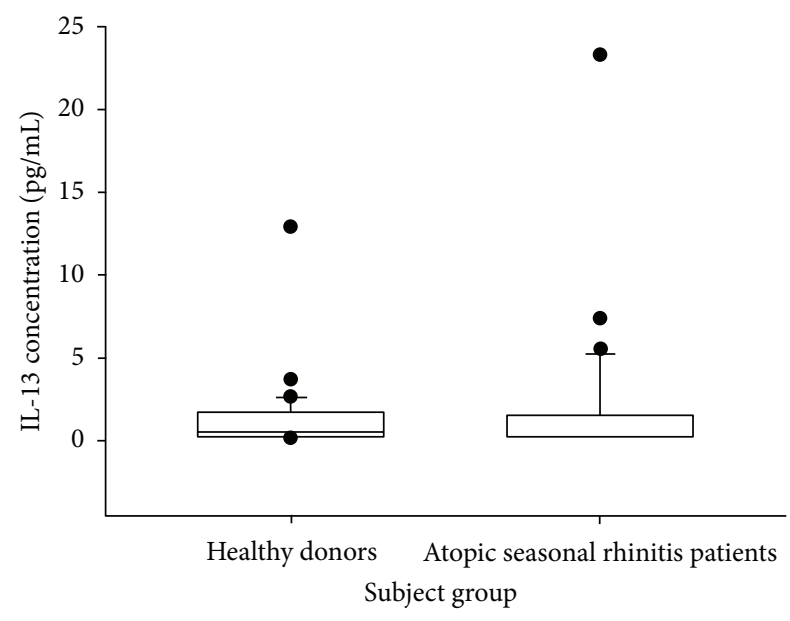

FIgURE 6: IL-13 concentration in EDTA plasma of healthy donors and atopic seasonal rhinitis patients.

$0.5 \mathrm{pg} / \mathrm{mL}$ (values below the LLOQ were assigned as LLOQ/2 $=0.3 \mathrm{pg} / \mathrm{mL}$ ), ranging from below limit of quantification to $12.99 \mathrm{pg} / \mathrm{mL}$. IL-13 can also be detected in $40 \%$ of atopic patient samples with a median of $0.3 \mathrm{pg} / \mathrm{mL}$ (values below the LLOQ were assigned as LLOQ $/ 2=0.3 \mathrm{pg} / \mathrm{mL}$ ), with a range from below limit of quantification to $23.24 \mathrm{pg} / \mathrm{mL}$. Taken altogether, the data demonstrated that the assay provides sensitive and reproducible measurement of IL-13 concentration in human plasma.

A strong overlap was observed over the ranges of distribution in the two subjects groups (Figure 6).

\section{Discussion}

As many other biomarkers, IL-13 circulates at very low levels in blood, in the low $\mathrm{pg} / \mathrm{mL}$ range. Besides, from our experience, the quantification of IL-13 at very low levels in complex matrices such as serum or plasma suffers from a lack of reproducibility that could be due to nonspecific binding and/or the presence of binding proteins. The study of the role of IL-13 in asthmatic and allergic diseases and the pharmacodynamic study of drugs in development require a sensitive and reproducible method of analysis. We herein described the development, validation, and implementation of a highly sensitive ELISA for the quantification of IL13 in human serum and plasma. All reagents used in the assay were commercially available, including capture and detection monoclonal antibodies. The ELISA included a sample incubation step under strong acidic conditions $(\mathrm{pH}$ 3.5) that allowed to reduce nonspecific binding, to improve inter-assay reproducibility, and to reduce interference from binding proteins.

To the best of our knowledge, so far, only one report described the use of an ELISA combining an acidic sample treatment with an antigen-antibody binding step performed under strong acidic conditions. In this report, Lakshman et al. applied a similar acidic treatment to suppress the interference of myostatin binding proteins and therefore were able to measure total circulating levels of myostatin in serum [17].
TABLE 3: Parallelism assessment of IL-13 assay in human plasma under acidic conditions. The accuracy was calculated using the IL13 concentration determined at dilution $1: 2$ as a reference value. Parallelism was considered acceptable when accuracy was between 70 and $130 \%$ for at least $5 / 6$ samples at each dilution.

\begin{tabular}{|c|c|c|c|}
\hline \multirow{2}{*}{ Dilution } & \multicolumn{2}{|c|}{ Raw result (pg/mL) } & \multirow{2}{*}{ Accuracy $(O / E, \%)$} \\
\hline & Observed $(O)$ & Expected $(E)$ & \\
\hline \multicolumn{4}{|c|}{ Sample 1} \\
\hline $1: 2$ & 0.425 & & \\
\hline $1: 3$ & 0.250 & 0.283 & 88.2 \\
\hline $1: 4$ & 0.195 & 0.213 & 91.8 \\
\hline $1: 6$ & N.C & N.C. & N.C. \\
\hline \multicolumn{4}{|c|}{ Sample 2} \\
\hline $1: 2$ & 1.280 & & \\
\hline $1: 3$ & 0.760 & 0.853 & 89.1 \\
\hline $1: 4$ & 0.525 & 0.640 & 82.0 \\
\hline $1: 6$ & 0.362 & 0.427 & 84.8 \\
\hline \multicolumn{4}{|c|}{ Sample 3} \\
\hline $1: 2$ & 0.745 & & \\
\hline $1: 3$ & 0.517 & 0.497 & 104.0 \\
\hline $1: 4$ & 0.425 & 0.373 & 114.1 \\
\hline $1: 6$ & 0.285 & 0.248 & 114.8 \\
\hline \multicolumn{4}{|c|}{ Sample 4} \\
\hline $1: 2$ & 1.190 & & \\
\hline $1: 3$ & 0.763 & 0.793 & 96.2 \\
\hline $1: 4$ & 0.540 & 0.595 & 90.8 \\
\hline $1: 6$ & 0.365 & 0.397 & 92.0 \\
\hline \multicolumn{4}{|c|}{ Sample 5} \\
\hline $1: 2$ & 1.330 & & \\
\hline $1: 3$ & 1.020 & 0.887 & 115.0 \\
\hline $1: 4$ & 0.830 & 0.665 & 124.8 \\
\hline $1: 6$ & 0.553 & 0.443 & 124.8 \\
\hline \multicolumn{4}{|c|}{ Sample 6} \\
\hline $1: 2$ & 0.270 & & \\
\hline $1: 3$ & 0.207 & 0.180 & 114.8 \\
\hline $1: 4$ & 0.148 & 0.135 & 109.3 \\
\hline $1: 6$ & N.C & N.C. & N.C. \\
\hline
\end{tabular}

N.C.: value not calculated as being outside the calibration range.

The authors had specifically produced antibodies able to bind myostatin at a low $\mathrm{pH}(\mathrm{pH} 2.5)$. The binding of IL13 by a commercial capture antibody was not expected to occur at a $\mathrm{pH}$ as low as $\mathrm{pH}$ 3.5. Indeed, the majority of antibodies immobilized on a solid support lose their capacity to bind their antigen at $\mathrm{pH} 4.5$ and below [18]. Besides, binding of IL-13 at low $\mathrm{pH}$ could not be observed when using a different mouse monoclonal anti-IL-13 antibody as the capture antibody (also of the IgG1 subtype). Hence, the properties observed with the commercial capture antibody could not be generalized to all mouse monoclonal antibodies.

$\mathrm{pH}$ influences protonation of ionizable amino acids on a protein, which are themselves involved in intraprotein, protein-solvent, protein-protein, and protein-ligand interactions [19]. The ability of an antibody to bind its antigen at 
TABLE 4: Selectivity assessment of IL-13 assay in human plasma under acidic conditions. $25.0 \mathrm{pg} / \mathrm{mL}$ of recombinant IL-13 was spiked in the same 6 plasma samples tested for parallelism. Accuracy was calculated using the IL-13 concentration determined at dilution $1: 2$ as a reference value. Selectivity was considered acceptable when accuracy was between 70 and $130 \%$ for at least 5/6 samples at each dilution.

\begin{tabular}{lccc}
\hline \multirow{2}{*}{ Dilution } & \multicolumn{2}{c}{ Raw result $(\mathrm{pg} / \mathrm{mL})$} & Accuracy $(\mathrm{O} / \mathrm{E}, \%)$ \\
& Observed $(O)$ & Expected $(E)$ & \\
\hline & \multicolumn{3}{c}{ Sample 1 } \\
$1: 2$ & 14.11 & & 99.5 \\
$1: 3$ & 9.36 & 9.41 & 109.1 \\
$1: 4$ & 7.70 & 7.06 & 102.8 \\
$1: 12$ & 2.42 & 2.35 & 102.5 \\
$1: 36$ & 0.80 & 0.78 & \\
\hline
\end{tabular}

Sample 2

\begin{tabular}{ll}
$1: 2$ & 13.99 \\
$1: 3$ & 9.64 \\
$1: 4$ & 7.25 \\
$1: 12$ & 2.48 \\
$1: 36$ & 0.85 \\
\hline
\end{tabular}

$1: 2 \quad 11.12$

$1: 3 \quad 8.28$

$1: 4 \quad 6.47$

$1: 12 \quad 2.45$

2.45
0.85

9.32

6.99

103.4

$\begin{array}{ll}.64 & 9.32 \\ 7.25 & 6.99\end{array}$

2.33

103.6

.48

0.78

106.4

Sample 3

$1: 36$

0.85

\subsection{1}

5.56

1.85

0.62

109.5

Sample 4

\begin{tabular}{ll}
$1: 2$ & 15. \\
$1: 3$ & 9.89 \\
$1: 4$ & 7.46 \\
$1: 12$ & 2.54 \\
$1: 36$ & 0.86 \\
\hline
\end{tabular}

\begin{tabular}{lrrr}
\hline & & Sample 5 \\
$1: 2$ & 14.87 & & \\
$1: 3$ & 10.07 & 9.91 & 101.6 \\
$1: 4$ & 7.50 & 7.43 & 100.8 \\
$1: 12$ & 2.69 & 2.48 & 108.4 \\
$1: 36$ & 0.99 & 0.83 & 119.4 \\
\hline \multicolumn{5}{c}{ Sample 6 }
\end{tabular}

$1: 2 \quad 13.16$

$1: 3 \quad 8.96$

$1: 4 \quad 6.78$

$1: 12 \quad 2.27$

2.27
N.R.

8.77

6.58

102.2

103.0

$1: 36$

N.R.

2.19

103.4

N.R.: not reported due to a technical issue.

*Value outside acceptance criteria.

low $\mathrm{pH}$ will therefore depend on its stability under acidic conditions and on the amino acids involved in the epitope and paratope regions. For instance, it has been shown that equilibrium characteristics of an antigen-antibody complex were more sensitive to $\mathrm{pH}$ variations when histidine residues (nonionizable amino acid) were involved in the interaction
TABLE 5: Sensitivity, working range, and intra- and interrun accuracy and precision of the IL-13 assay under acidic conditions. Interand intrarun accuracy and precision were determined based on five levels of QCs ranging from the LLOQ to the ULOQ, assessed over six runs and five preparations per run.

\begin{tabular}{lc}
\hline Parameters & Performance \\
\hline $\begin{array}{l}\text { Sensitivity } \\
\text { Working range }\end{array}$ & $0.59 \mathrm{pg} / \mathrm{mL}$ \\
$\begin{array}{l}\text { Intrarun accuracy and } \\
\text { precision }\end{array}$ & LLOQ: $0.59 \mathrm{pg} / \mathrm{mL}$; ULOQ: $68.4 \mathrm{pg} / \mathrm{mL}$ \\
& Accuracy: $84.6 \%$ to $116.2 \%$ \\
$\begin{array}{l}\text { Interrun accuracy and } \\
\text { precision }\end{array}$ & Precision: $1.1 \%$ to $11.2 \%$ \\
& Accuracy: 98.2 to $105.5 \%$ \\
\hline
\end{tabular}

[18]. It is therefore very likely that only few ionizable amino acids were involved in the binding between IL-13 and the capture antibody (in IL-13, these amino acids represent $21 \%$ of the whole sequence). In addition, the capture antibody was remarkably stable at $\mathrm{pH} 3.5$. We could observe that binding of IL-13 by this antibody at $\mathrm{pH} 3.5$ could not occur in solution but only occurred when the antibody had been immobilized on a solid phase (data not shown). It has been well established that proteins generally undergo conformational changes upon their adsorption on synthetic surfaces [20-22]. These changes in the conformation are frequently associated with modifications in immunoreactive properties of adsorbed proteins [23-27]. Indeed, conformational changes linked to immobilization of an antibody can lead to steric hindrance or the alteration of the paratope region and therefore to a change of its affinity for the antigen. Moreover, kinetic parameters of the antigen-antibody interaction are modified in solid-liquid phase as compared to liquid-liquid phase interaction. In a general manner, monoclonal antibodies have a lower affinity for their antigen when they are adsorbed on a solid support than when they are in solution $[28,29]$. In the opposite, the immobilization of our capture antibody improved the capture of IL-13 at low $\mathrm{pH}$.

It is possible that detection of IL-13 is partially inhibited at low $\mathrm{pH}$; however, this effect should be compensated by the use of a calibration curve prepared in the same conditions (IL13 in a buffer at low $\mathrm{pH}$ containing serum proteins to mimic human serum and plasma).

We could show that interference of IL-13R $\alpha 2$, one of the soluble IL-13 binding proteins, was strongly diminished at low $\mathrm{pH}$. The influence of binding proteins on the quantification of IL-13 depends on their concentration, on their affinity for IL-13 at low $\mathrm{pH}$, and on the affinity of assay capture antibody under the same conditions. $90.1 \%$ of recombinant IL-13 concentration could be recovered in the presence of a 100 -fold molar excess of its high affinity receptor rhIL-13R $\alpha 2$. Incertitude remains on the endogenous concentrations of IL$13 \mathrm{R} \alpha 2$ in human circulation, but recent studies tend to prove that they do not exceed $250 \mathrm{pg} / \mathrm{mL}$ in the serum of healthy and asthmatic subjects, far below our tested concentrations [15]. Our results obtained with recombinant proteins suggest 
TABLE 6: Stability assessment of endogenous IL-13 in human plasma. Two different human plasma samples (3.75 and $1.16 \mathrm{pg} / \mathrm{mL}$ of endogenous IL-13) were stored undiluted under different temperatures and time periods or subjected to freeze and thaw cycles. Recovery of IL-13 concentration was calculated using the concentration measured at Day 1 (T0) as a reference value.

\begin{tabular}{lccc}
\hline & Storage conditions & Mean recovery (\%) & Range of recovery (\%) \\
\hline \multirow{3}{*}{ Short-term stability } & $25^{\circ} \mathrm{C}, 1$ week & 77.2 & $72.3-81.9$ \\
& $4^{\circ} \mathrm{C}, 1$ week & 82.3 & $74.0-94.3$ \\
& $-20^{\circ} \mathrm{C}, 1$ month & 80.7 & $77.4-83.3$ \\
Freeze/thaw stability & $-80^{\circ} \mathrm{C}, 1$ month & 76.1 & $73.9-78.2$ \\
& 3 cycles at $-20^{\circ} \mathrm{C}$ & 92.2 & $73.6-112.5$ \\
\hline
\end{tabular}

that incubation at low $\mathrm{pH}$ allows to measure the total concentration of IL-13 and not only the free fraction (i.e., not bound to a receptor).

The measurement of healthy and atopic subjects samples has shown that IL-13 can be quantified in about $40 \%$ of the samples. The quantified levels are consistent with data reported by Ledger et al. and Gauvreau et al., who used a bead-based immunoassay designed to quantify total IL-13 $[8,9]$. There was no difference in circulating IL-13 levels between healthy and atopic subjects. If the use of IL-13 as a systemic biomarker to monitor disease activity is limited, the assessment of IL-13 levels locally at the site of the disease may provide more relevant clinical use (e.g., from lung samples). However, the method will be useful to monitor systemic IL-13 as a pharmacodynamic biomarker for drugs directly targeted towards IL-13, especially as no drug interference is to be expected due to the acidic treatment applied.

The sensitivity and validation data characterize this ELISA as a suitable method for the quantification of IL-13 in human plasma and human serum. Additional development and validation work could also allow to enlarge the method for the measurement of IL-13 in other matrices such as sputum, bronchoalveolar lavage fluid, or serum and plasma from preclinical species (mouse, rat, dog, or monkeys) if the interference of binding proteins is observed in these matrices. The use of this method could allow a better understanding of the implication of IL-13 in pathologies such as allergy or asthma and of the pharmacodynamic effect of new therapeutic drugs.

There are many other biomarkers for which soluble binding proteins have been identified, as for instance IL1 [30], IL-4 [31], IL-18 [32], or IGF-1 [33], and it is very likely that the problem of interfering binding proteins will occur in more and more cases. Besides, the same problem is encountered when setting up assays for the measurement of the target bound to a therapeutic antibody [34]. Results obtained with IL-13 under acidic conditions open new perspectives on how to build an immunoassay for analytes with interfering binding partners with high affinity for the analyte. For instance, antibodies may be generated and selected based on their ability to bind specifically an analyte under predetermined stringent or denaturing conditions (acidic or alkaline $\mathrm{pH}$, chaotropic salts, organic solvents, detergents, high temperatures, etc.).

\begin{abstract}
Abbreviations
AP: $\quad$ Alkaline phosphatase

BAL: Bronchoalveolar lavage

BSA: Bovine serum albumin

$\mathrm{CV}$ : Coefficient of variation

FBS: Fetal bovine serum

HRP: Horseradish peroxidase

IL-13: Interleukin-13

LLOQ: Lower limit of quantification

MRD: Minimum required dilution

NSB: Nonspecific binding

QC: Quality control

RT: $\quad$ Room temperature

ULOQ: Upper limit of quantification.
\end{abstract}

\section{Highlights}

(i) A novel sandwich ELISA for the quantitative and sensitive determination of IL-13 in human serum and plasma was established. (ii) The assay employs an incubation step at acidic $\mathrm{pH}$, which was shown to decrease nonspecific binding and interference from IL-13 binding proteins. (iii) The assay was validated and was shown to be accurate and precise over the entire quantification range $(0.59$ to $68.4 \mathrm{pg} / \mathrm{mL}$ in human EDTA plasma). (iv) The validated assay was successfully applied to samples from healthy volunteers and patients with atopic seasonal rhinitis. (v) The assay is suitable for use in clinical trials to monitor efficacy or pharmacodynamic effects of drug candidates.

\section{References}

[1] J. Mitchell, V. Dimov, and R. G. Townley, "IL-13 and the IL-13 receptor as therapeutic targets for asthma and allergic disease," Current Opinion in Investigational Drugs, vol. 11, no. 5, pp. 527534, 2010.

[2] M. Wills-Karp, "Interleukin-13 in asthma pathogenesis," Immunological Reviews, vol. 202, pp. 175-190, 2004.

[3] A. M. Fitzpatrick, M. Higgins, F. Holguin, L. A. S. Brown, and W. G. Teague, "The molecular phenotype of severe asthma in children," Journal of Allergy and Clinical Immunology, vol. 125, no. 4, pp. 851.e18-857.e18, 2010.

[4] A. B. Becker, "Challenges to treatment goals and outcomes in pediatric asthma," Journal of Allergy and Clinical Immunology, vol. 109, no. 6, pp. S533-S538, 2002. 
[5] T. L. Noah, G. E. Tudor, S. S. Ivins, P. C. Murphy, D. B. Peden, and F. W. Henderson, "Repeated measurement of nasal lavage fluid chemokines in school-age children with asthma," Annals of Allergy, Asthma and Immunology, vol. 96, no. 2, pp. 304-310, 2006.

[6] W. Feleszko, A. Zawadzka-Krajewska, K. Matysiak et al., "Parental tobacco smoking is associated with augmented IL-13 secretion in children with allergic asthma," Journal of Allergy and Clinical Immunology, vol. 117, no. 1, pp. 97-102, 2006.

[7] O. Eickmeier, M. Huebner, E. Herrmann et al., "Sputum biomarker profiles in cystic fibrosis (CF) and chronic obstructive pulmonary disease (COPD) and association between pulmonary function," Cytokine, vol. 50, no. 2, pp. 152-157, 2010.

[8] G. M. Gauvreau, L.-P. Boulet, D. W. Cockcroft et al., "Effects of interleukin-13 blockade on allergen-induced airway responses in mild atopic asthma," American Journal of Respiratory and Critical Care Medicine, vol. 183, no. 8, pp. 1007-1014, 2011.

[9] K. St. Ledger, S. J. Agee, M. T. Kasaian et al., "Analytical validation of a highly sensitive microparticle-based immunoassay for the quantitation of IL-13 in human serum using the Erenna immunoassay system," Journal of Immunological Methods, vol. 350, no. 1-2, pp. 161-170, 2009.

[10] Y. C. Lee, K. H. Lee, H. B. Lee, and Y. K. Rhee, "Serum levels of interleukins (IL)-4, IL-5, IL-13, and interferon- $\gamma$ in acute asthma," Journal of Asthma, vol. 38, no. 8, pp. 665-671, 2001.

[11] L. Wang, X. Zhang, Y.-W. Xue, Y. Li, Q. Shi, and C.-H. Liu, "Changes of serum interleukin (IL)-12 and IL-13 in asthmatic patients and regulatory effects of glucocorticoids on them," Zhonghua Nei Ke Za Zhi, vol. 42, no. 1, pp. 24-26, 2003.

[12] K. Arima, K. Sato, G. Tanaka et al., "Characterization of the interaction between interleukin-13 and interleukin-13 receptors," The Journal of Biological Chemistry, vol. 280, no. 26, pp. 24915-24922, 2005.

[13] W. Chen, U. Sivaprasad, Y. Tabata et al., "IL-13R $\alpha 2$ membrane and soluble isoforms differ in humans and mice," The Journal of Immunology, vol. 183, no. 12, pp. 7870-7876, 2009.

[14] M. O. Daines, W. Chen, Y. Tabata et al., "Allergen-dependent solubilization of IL-13 receptor $\alpha 2$ reveals a novel mechanism to regulate allergy," Journal of Allergy and Clinical Immunology, vol. 119, no. 2, pp. 375-383, 2007.

[15] M. O’Toole, H. Legault, R. Ramsey, T. A. Wynn, and M. T. Kasaian, "A novel and sensitive ELISA reveals that the soluble form of IL-13R- $\alpha 2$ is not expressed in plasma of healthy or asthmatic subjects," Clinical and Experimental Allergy, vol. 38, no. 4, pp. 594-601, 2008.

[16] M.-A. Valentin, S. Ma, A. Zhao, F. Legay, and A. Avrameas, "Validation of immunoassay for protein biomarkers: bioanalytical study plan implementation to support pre-clinical and clinical studies," Journal of Pharmaceutical and Biomedical Analysis, vol. 55 , no. 5, pp. 869-877, 2011

[17] K. M. Lakshman, S. Bhasin, C. Corcoran et al., "Measurement of myostatin concentrations in human serum: circulating concentrations in young and older men and effects of testosterone administration," Molecular and Cellular Endocrinology, vol. 302, no. 1, pp. 26-32, 2009.

[18] E. Sada, S. Katoh, A. Kiyokawa, and A. Kondo, "Effect of histidine residues in antigenic sites on $\mathrm{pH}$ dependence of immuno-adsorption equilibrium," Applied Microbiology and Biotechnology, vol. 27, no. 5-6, pp. 528-532, 1988.

[19] C. N. Pace, G. R. Grimsley, and J. M. Scholtz, "Protein ionizable groups: $\mathrm{pK}$ values and their contribution to protein stability and solubility," The Journal of Biological Chemistry, vol. 284, no. 20, pp. 13285-13289, 2009.

[20] H. B. Bull, "Adsorption of bovine serum albumin on glass," Biochimica et Biophysica Acta, vol. 19, pp. 464-471, 1956.

[21] B. W. Morrissey and C. A. Fenstermaker, "Conformation of adsorbed gamma-globulin and beta-lactoglobulin. Effect of surface concentration," Transactions American Society for Artificial Internal Organs, vol. 22, pp. 278-284, 1976.

[22] M. E. Soderquist and A. G. Walton, "Structural changes in proteins adsorbed on polymer surfaces," Journal of Colloid And Interface Science, vol. 75, no. 2, pp. 386-397, 1980.

[23] L. Djavadi-Ohaniance, B. Friguet, and M. E. Goldberg, "Structural and functional influence of enzyme-antibody interactions: effects of eight different monoclonal antibodies on the enzymatic activity of Escherichia coli tryptophan synthase," Biochemistry, vol. 23, no. 1, pp. 97-104, 1984.

[24] Z. Hollander and E. Katchalski-Katzir, "Use of monoclonal antibodies to detect conformational alterations in lactate dehydrogenase isoenzyme 5 on heat denaturation and on adsorption to polystryrene plates," Molecular Immunology, vol. 23, no. 9, pp. 927-933, 1986.

[25] S. J. Kennel, "Binding of monoclonal antibody to protein antigen in fluid phase or bound to solid supports," Journal of Immunological Methods, vol. 55, no. 1, pp. 1-12, 1982.

[26] S. Kochwa, M. Brownell, R. E. Rosenfield, and L. R. Wasserman, "Adsorption of proteins by polystyrene particles. I. Molecular unfolding and acquired immunogenicity of IgG," The Journal of Immunology, vol. 99, no. 5, pp. 981-986, 1967.

[27] F. J. Stevens, J. Jwo, and W. Carperos, "Relationships between liquid- and solid-phase antibody association characteristics: implications for the use of competitive ELISA techniques to map the spatial location of idiotopes," The Journal of Immunology, vol. 137, no. 6, pp. 1937-1944, 1986.

[28] J. E. Butler, "The behaviour of antigens and antibodies immobilized on a solid phase," in Structure of Antigens, M. H. V. Van Regenmortel, Ed., pp. 209-259, 1991.

[29] J. E. Butler, L. Ni, R. Nessler et al., "The physical and functional behavior of capture antibodies adsorbed on polystyrene," Journal of Immunological Methods, vol. 150, no. 1-2, pp. 77-90, 1992.

[30] C. A. Dinarello, "Interleukin-1 and interleukin-1 antagonism," Blood, vol. 77, no. 8, pp. 1627-1652, 1991.

[31] T. Silvestri, L. Pulsatelli, P. Dolzani, A. Facchini, and R. Meliconi, "Elevated serum levels of soluble interleukin-4 receptor in osteoarthritis," Osteoarthritis and Cartilage, vol. 14, no. 7, pp. 717-719, 2006.

[32] B. Bresnihan, P. Roux-Lombard, E. Murphy, D. Kane, O. FitzGerald, and J.-M. Dayer, "Serum interleukin 18 and interleukin 18 binding protein in rheumatoid arthritis," Annals of the Rheumatic Diseases, vol. 61, no. 8, pp. 726-729, 2002.

[33] F. Mashayekhi, E. Mirzajani, M. Naji, and M. Azari, "Expression of insulin-like growth factor-1 and insulin-like growth factor binding proteins in the serum and cerebrospinal fluid of patients with Parkinson's disease," Journal of Clinical Neuroscience, vol. 17, no. 5, pp. 623-627, 2010.

[34] J. Doucet and A. Avrameas, "A novel method for quantitative measurement of a therapeutic monoclonal antibody in the presence of its target protein using enzymatic digestion," Journal of Pharmaceutical and Biomedical Analysis, vol. 52, no. 4, pp. 565-570, 2010. 


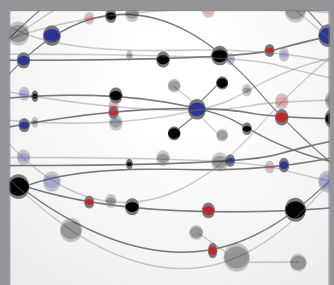

The Scientific World Journal
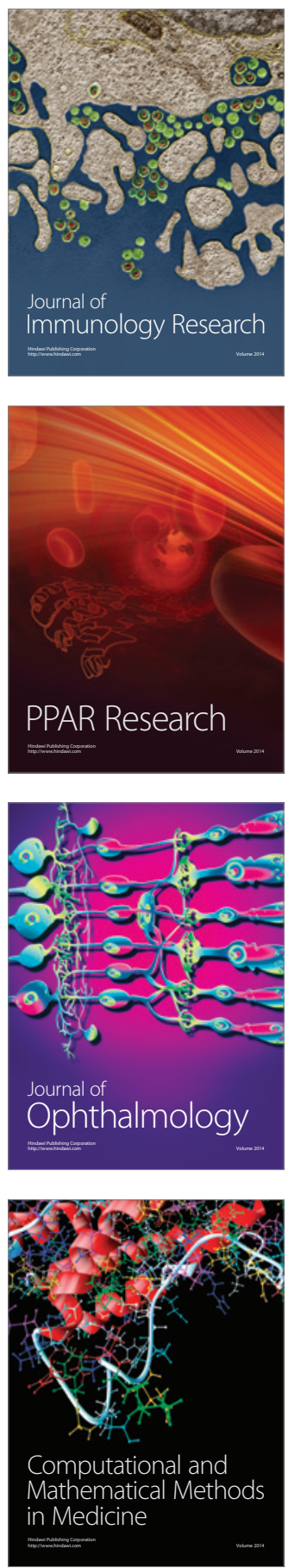

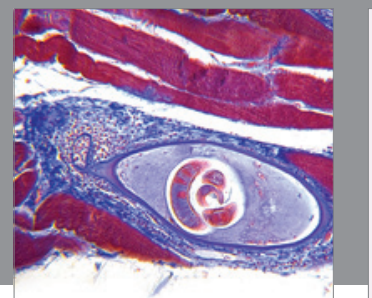

Gastroenterology

Research and Practice
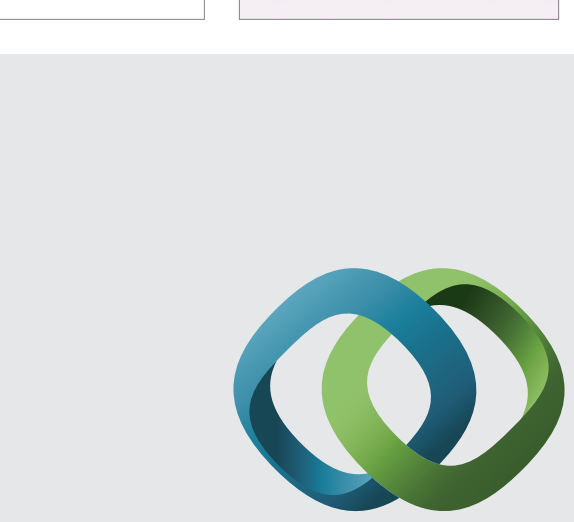

\section{Hindawi}

Submit your manuscripts at

http://www.hindawi.com
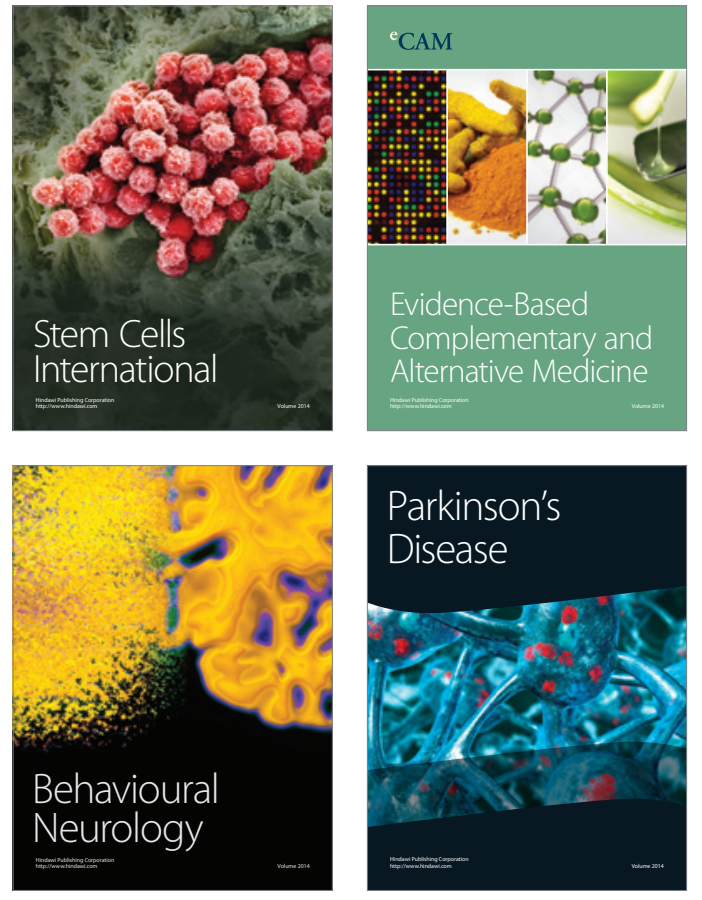
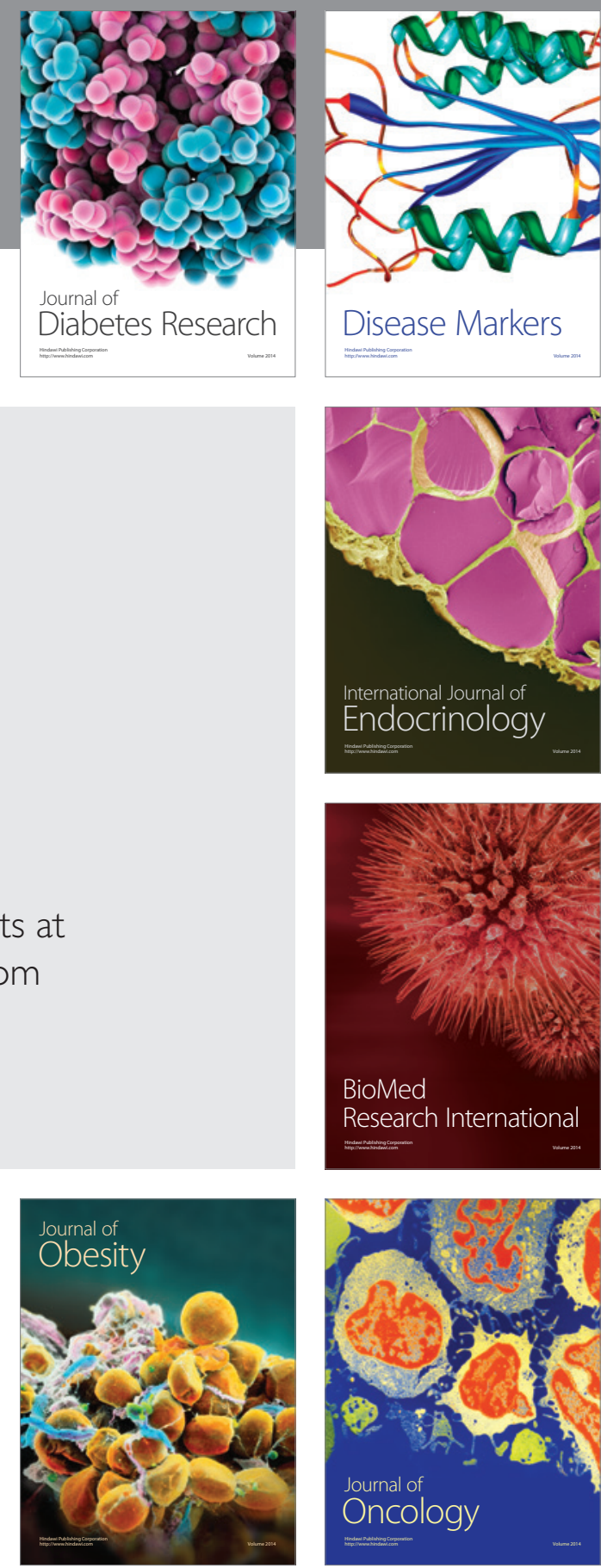

Disease Markers
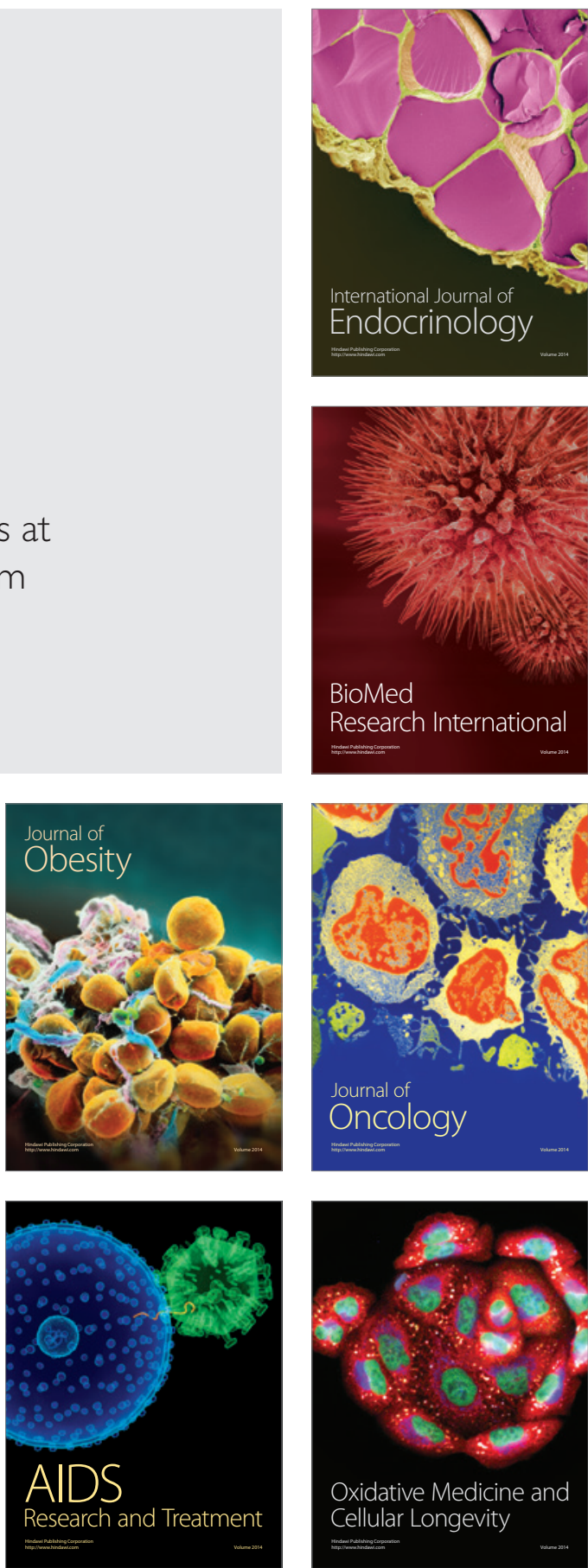